$<$ 原 著 $>$

\title{
臨床検査技師を含む多職種連携による院内肝炎ウイルス検査陽性者 受診勧奨の取り組み
}

\begin{tabular}{|c|c|c|c|c|c|c|}
\hline 勲 ${ }^{12)}$ * & 大野 & 高嗣1) & 藤永 & 覀季 ${ }^{3)}$ & 増井美由紀 ${ }^{4)}$ & 久永 \\
\hline 一成 ${ }^{2)}$ & 松本 & 俊彦 ${ }^{2)}$ & 丸本 & 芳雄 ${ }^{2)}$ & 石川 剛 ${ }^{2)}$ & 高見 \\
\hline 伶緒5) & 山㟝 & 隆弘 ${ }^{3)}$ & 坂井 & 功 ${ }^{12)}$ & & \\
\hline
\end{tabular}

\begin{abstract}
要旨：術前検査などで肝炎ウイルス検査を実施することが一般的となっている. 陽性者に対する 受診针奨の施策として, 電子カルテアラートシステムが普及しつつあるが, その効果は限定的と の報告もある．当院では電子カルテアラートシステム導入に加え, 2016 年 7 月より非専門診療 科毎の勉強会を実施, 2019 年 7 月より臨床検査技師を含む多職種連携による個別钊奨を実施し てきたので, 取り組みの効果を検証した. 非専門診療科における陽性者への対応率は診療科毎の 勉強会実施後上昇した.さらに多職種連携による個別搉奨後の対応率は $92.0 \%$ と飛躍的に上昇し た. 受診勧奨を契機に B 型肝炎 20 例で核酸アナログ製剤投与が， C 型肝炎 32 例で直接型抗ウ イルス薬（DAA）治療が開始された。また, DAA 治療症例の受診契機として，2017 年以降， 院内紹介の割合が増加していた. 院内受診勧奨には診療科毎の勉強会や多職種連携による個別锥 奨は有用である。
\end{abstract}

索引用語： 肝炎ウイルス 受診钦奨 多職種連携 肝炎医療コーディネーター 臨床検査技師

\section{緒言}

わが国には 2011 年時点で $98-158$ 万人の HCV 持続感 染者が, 112-127 万人の HBV 持続感染者がいると推測 されている ${ }^{1)}$. 持続的な $\mathrm{HBV}$ および $\mathrm{HCV}$ 感染を放置す ると肝硬変や肝細胞癌に進行することが知られており, 実際にわが国における肝細胞癌(HCC)の原因の約 70\% は HCV もしくは HBV に起因するものである ${ }^{2)}$. 近年, ウイルス性肝炎に対する治療の進歩は目覚ましく, 抗 ウイルス治療により, 肝疾患の病状進行や肝発癌は抑 制可能となってきた ${ }^{3) \sim 5)}$. それゆえ, 患者の早期発見, 早期治療介入が重要であり, 肝炎ウイルス無料検査や 治療費助成制度など，厚生労働省が中心となって総合

1）山口大学医学部附属病院肝疾患センター

2) 山口大学大学院医学系研究科消化器内科学

3）山口大学医学部附属病院検査部

4) 山口大学医学部附属病院看護部

5）広島大学病院広島臨床研究開発支援センター

*Corresponding author: isao-h@yamaguchi-u.ac.jp <受付日2021年3月5日 $><$ 採択日2021年4月19日 $>$
的な肝炎対策が施行され，肝炎ウイルス陽性者が適切 な医療機関を受診できるような様々な取り組みが実施 されている6 ${ }^{6}$.

医療機関においては医療安全の観点などから, 術前 および侵襲的検查前スクリーニング検査として肝炎ウ イルス検查を実施することが一般的となっているが, 肝炎ウイルス検査陽性であった患者への適切な結果説 明や専門医への受診につながっていない症例もあり， 課題となっている. 術前検査等による院内肝炎検査陽 性者に対する受診针奨の施策として, 電子カルテアラー トシステムを用いた非専門医への勧奨の有用性が報告 されており ${ }^{778)}$, 肝疾患診療連携拠点病院を中心に電子 カルテ自動アラートシステムが普及しつつある.

しかしながら,「職域等も含めた肝炎ウイルス検査受 検率向上と陽性者の効率的なフォローアップシステム の開発・実用化に向けた研究班」で実施した自動アラー トシステムを導入している医療機関対象の非専門医に 対する意識調査の結果, 非専門医における肝炎ウイル ス陽性者の専門医受診の必要性の認識は $40 \%$ 未満であ 


\section{・2015年4月に電子カルテ自動アラートシステム導入}

・2015年に医療安全講習会で電子カルテ自動アラートシステム周知

・2016年7月から2019年3月に各診療科での勉強会実施 看護師（肝Co）にも併せて説明、協力依頼

・2019年7月より 多職種連携による個別勧奨開始 臨床検査技師（肝Co）による陽性者拾い上げ（1週間毎） と肝疾患センター看護師（肝Co）・医師による個別勧奨

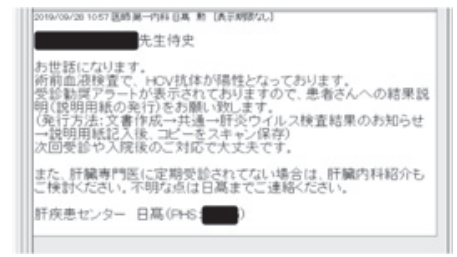

図 1 非専門診療科肝炎ウイルス検査陽性者に対する院内受診勧奨の取り組 み. 電子カルテ自動アラートシステム導入後に当院で実施した受診勧奨の 取り組みの年次推移

肝 Co ; 肝炎医療コーディネーター

ることが判明した ${ }^{9)}$ ．実際，当院においても 2015 年 4 月に電子カルテ自動アラートシステムを導入したが, 肝炎ウイルス陽性者に対する適切な結果説明は十分に 行えていなかった，そこで，非専門医への個別研修会 やメディカルスタッフを含む多職種連携での受診钦奨 取り組みを実施し，陽性者への適切な対応向上につな がるか効果検証した.

\section{方法}

\section{1. 院内受診勧奨の取り組み（図 $\mathbf{1}$ )}

医療安全講習会での周知

山口大学医学部附属病院では 2015 年 4 月より HBs 抗原陽性, HCV 抗体陽性患者に対する電子カルテ自動 アラートシステム (図 2a) を導入, 2015 年度の医療安 全講習会で全職員を対象にシステムについて周知し， 結果説明用紙（図 $2 \mathrm{~b}$ ) を用いた適切な結果説明を行う よう周知した.

非専門診療科毎勉強会の開催

2016 年 7 月から 2019 年 3 月にかけて非専門診療科を 対象に診療科毎に C 型肝炎に対する直接型抗ウイルス 薬 $(\mathrm{DAA})$ 治療や HBV 再活性化, HBV キャリア発癌 のリスクといったウイルス性肝炎に関する講義と肝炎 検查陽性者の専門医受診の必要性, 電子カルテ自動ア ラートシステムの対応方法に関する勉強会を実施した. 可能な限り各診療科の病棟看護師にも同席を依頼し，
看護師に未対応医師への対応钊奨を依頼した。

臨床検査技師を含む多職種連携での個別勧奨

さらに電子カルテ自動アラートシステムとは別に, 臨床検查技師の肝炎医療コーディネーターの役割とし て院内受診勧奨に関わってほしいことを検查部に相談 し, 担当検査技師を選出, 臨床検査技師と肝疾患セン ター専任看護師，専任医師による多職種連携での受診 勧奨のシステムを構築した。具体的には 1 週間毎の肝 臓内科・肝臟外科以外に扔ける HBs 抗原 ・ HCV 抗体陽 性者を臨床検查技師が把握し, 肝疾患センター専任看 護師に報告, 看護師は肝臟内科および肝臟外科への通 院歴，受診歴を確認し，1 年以内に受診歷がなければ, 電子カルテ上の揭示板で主治医に結果説明と院内紹介 の依頼を肝疾患センター専任医師名義で記載，判断に 困った症例は肝疾患センター専任医師に確認し必要な 症例には記載することとし，専任医師は主治医からの 個別相談対応を受ける体制を構築し，医療安全委員会 の承認後, 2019 年 7 月から個別勧奨を開始した.

\section{2. 院内受診勧奨の効果検証}

検討 $1:$ アラートの発令数と対応率の推移

2015 年 4 月から 2019 年 12 月までの肝臟内科, 肝臓 外科を除く診療科に扔ける HBs 抗原陽性もしくは HCV 抗体陽性による電子カルテアラート発令数を年次毎, 診療科毎に集計した。 アラート発令後 6 力月以内に肝 疾患センターで作成した結果説明用紙を用いた結果説 
a)

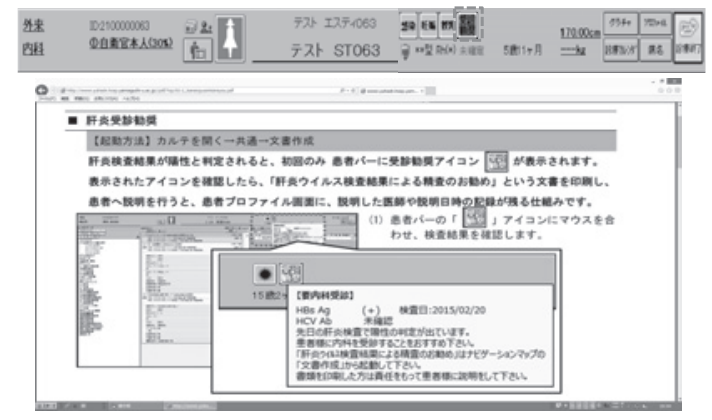

b)

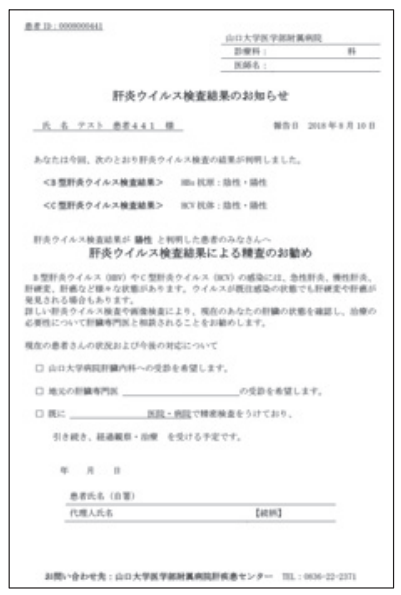

図 2 電子カルテ自動アラートシステムのイメージ a）患者画面のアラート表示. 肝炎ウイルス検査が陽性であった場合の電子カルテ上 の患者画面での表示イメージ. 文献 9 より引用改変. b) 肝炎ウイルス陽性結果説明 用紙. 肝疾患センターで作成した当院で利用している結果説明の共通書式.

明が行われた（直接肝臓内科へ院内紹介された症例を 含む）症例を適切な対応ありと評価し，対応率の推移 について検討した.

検討 $2:$ 受診锥奨後紹介例の病状実態調査

2015 年 4 月から 2019 年 12 月に電子カルテアラート が発令された症例のうち, 肝臓内科に院内紹介となっ た症例における初診時診断およびその後の抗ウイルス 治療の受療状況についてカルテ上で調査を実施した.

検討 $3:$ DAA 治療症例における受診契機の検討 電子カルテ自動アラートを導入した 2015 年以降に肝 臓内科で C 型慢性肝炎・肝硬変症に対し DAA 治療を 実施した症例における治療開始時の受診契機について カルテ記載より調查を行い，院内紹介率の推移を検証 した.

\section{3. 統計学的解析}

受診勧奨アラート発令に対する対応件数の経年推移 について, 年度別 (2015 年度・ 2016 年度・ 2017 年度・ 2018 年度・ 2019 年 $4 \sim 6$ 月・ 2019 年 7 12 月) の対応 割合を Cochran-Armitage 傾向検定で解析した. また, 2015 年度と各年度の対比を $\chi^{2}$ 検定で解析し, Bonferroni 補正した. DAA 治療症例の受診契機の経年推移につい ては $\chi^{2}$ 検定で解析した. 統計解析には JMP ${ }^{\circledR}$ Pro 14(SAS Institute Japan, Tokyo, Japan)を用い, $\mathrm{P}<0.05$ を統 計学的有意とした.

\section{結果}

検討 $1:$ 受診勧奨アラートの発令数と対応率を図 3 に示す. 対応率は経年的に上昇する傾向 $(\mathrm{p}<0.0001)$ に あり, 特に 2019 年 7-12 月の対応率は $92.0 \%$ と, いずれ の年度と比較しても有意に高かった $(\mathrm{p}<0.001) .2015$ 年 4 月から 2019 年 12 月に扔ける診療科別アラート数 を図 4 に示す. 眼科 136 件, 整形外科 92 件と高齢者に 対する手術加療を行う診療科で陽性者が多かった。

検討 2 : 受診アラート発令 994 例中 326 例 (34.5\%) が 肝臓内科に紹介となった。紹介患者の紹介時診断と抗 ウイルス薬の投与状況を表 1 に示す. HBs 抗原陽性例 では紹介時に 4 例で HCC を認め, 肝硬変 1 例, 慢性肝 炎 5 例で新たに核酸アナログ製剤投与が開始された. セロコンバージョン後のキャリアにおいても14例でHBV 再活性化予防目的の核酸アナログ製剂投与が開始され, この中にはすでに化学療法開始後の適切な再活性化対 策が行えていない症例も含まれていた. HCV 抗体陽性 例では 3 例で HCC を認め (他院で HCC 加療中 1 例を 含む), 肝硬変 4 例, 慢性肝炎 28 例で DAA 治療が開始 された。

検討 3 : 電子カルテアラートシステムを導入した 2015 年 4 月から 2020 年 3 月までに肝臓内科で 279 例にC 型慢性肝炎・肝硬変に対し DAA 治療が実施された。 DAA 症例における年度毎の症例数と受診契機の比率を 


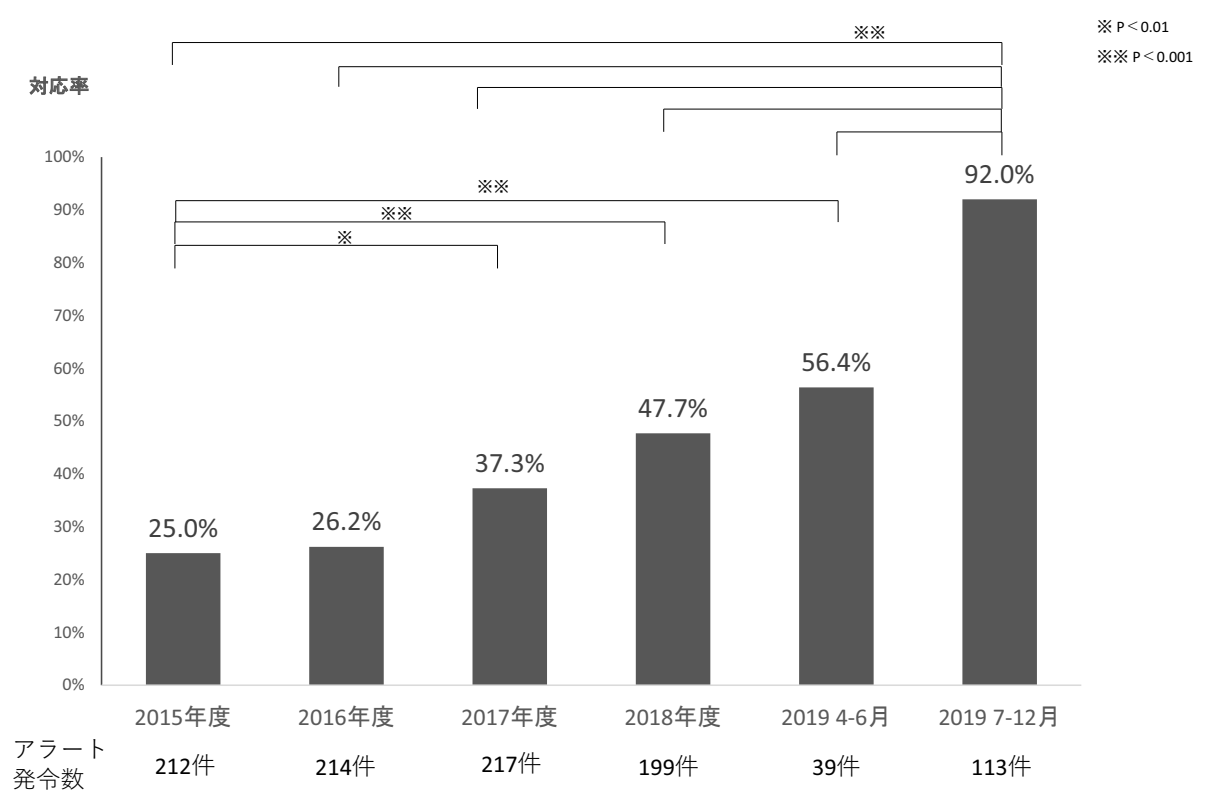

図 3 受診勧奨アラート発令件数と対応率の推移

各年度における対応率について有意差を認めるものに※P $<0.01, ※ ※ \mathrm{P}<0.001$ を付記（ $\chi 2$ 乗 検定). 2019 年 7 月- 12 月はいずれの年度と比較しても有意に対応率は上昇していた.

図 5 に示す。院内紹介の割合は 2015 年 $6.9 \%, 2016$ 年 $13.7 \%, 2017$ 年 $33.3 \%, 2018$ 年 $20.8 \%, 2019$ 年 $38.5 \%$ であった. 2017 年以降, 受診契機として院内紹介の割 合が増加しており，年代により受診契機が異なってい た $\left(\mathrm{P}<0.0001, \chi^{2}\right.$ 検定 $)$.

\section{考察}

わが国では 2009 年に肝炎対策基本法が施行され, 国 を挙げて肝炎対策が実施されている ${ }^{6}$. 肝炎ウイルスが 陽性にも関わらず，適切な医療を受けていない患者が 多く存在することが知られており ${ }^{1)}$, 未受診への受診勧 奨も重要な課題である。術前検查等の院内検査で肝炎 ウイルス陽性が判明する機会は多く，陽性者への院内 受診勧奨は適切な受診への取り組みとして重要であり, 我が国では電子カルテ自動アラートシステムが普及し つつある. 当院でも 2015 年 4 月に電子カルテ自動アラー トシステムを導入し, 医療安全講習会で周知した。し かし, 電子カルテ自動アラートの効果は限定的との報 告があり ${ }^{10}$, 著者らが研究班で実施した意識調査でも電 子カルテアラートによる院内紹介の必要性の認知度は 低く，その要因として非専門医のウイルス性肝炎に対 する知識不足があることが判明し，さらなる対策が必
要であると考えられた ${ }^{9}$. 非専門医に対する知識向上の ため, 当院では 2016 年 7 月から,眼科や整形外科といっ た陽性者が多く判明する診療科を中心に，診療科毎に ウイルス性肝炎に関する講義と電子カルテ自動アラー トシステムへの対応方法抒よび専門医未受診者の院内 紹介の必要性について説明を開始した。勉強会開始前 の 2015 年の術前検查等における肝炎ウイルス陽性者へ の対応率は $25.0 \%$ と低率であったが, 勉強会開始後, 2016 年 $26.2 \%, 2017$ 年度 $37.3 \%, 2018$ 年度 $47.7 \%, 2019$ 年 4-6 月 $56.4 \%$ と勉強会を実施した診療科が増加する毎 に対応率も年々上昇し, 個別の勉強会による非専門医 への知識の向上は対応率改善につながることが判明し た。また，看護師も勉強会に参加し，話し合いを実施 した結果, 当院眼科および整形外科病棟では, 入院患 者には外来で実施された術前検査の結果説明の有無を 入院時に看護師が確認し, 未対応医師へ勧奨すること となり, 白内障手術などの短期入院であっても，ほと んどの症例で結果説明や受診希望者への肝臓内科院内 紹介が可能となった.

このように診療科毎の勉強会実施により, 電子カル テ自動アラートのみと比較し, 相加的に対応率の向上 が得られたものの, 対応率は 2018 年度も $50 \%$ 未満で 


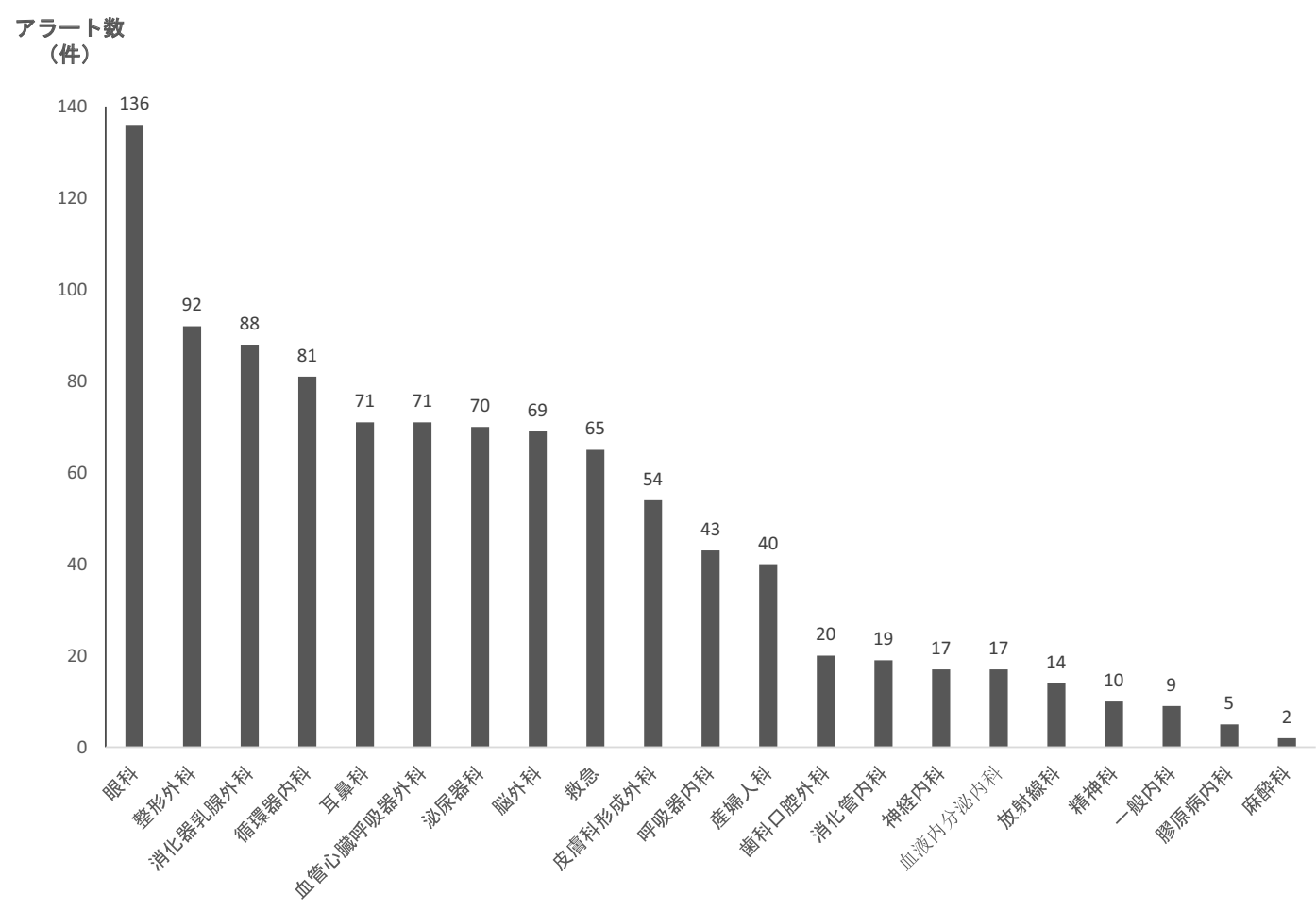

図 4 診療科別受診钓奨アラート発令数

2015 年 4 月から 2019 年 12 月における各診療科における HBs 抗原陽性もしくは HCV 抗体陽性のため発令さ れたアラート数 $(\mathrm{n}=993)$.

表 1 受診勧奨アラート後肝臟内科紹介時診断と受療状況 $(\mathrm{n}=326)$

\begin{tabular}{cccc}
\hline 紹介理由 & 診断 & 受療状況 & 症例数 \\
\hline HBs 抗原陽性 & 肝細胞癌 & & 4 \\
& 肝硬変 & NA 開始 & 2 (他院加療中 1 例) \\
& 慢性肝炎 & NA 開始 & 5 \\
& SC 後キャリア & 経過観察 & 1 \\
& & 再活性化予防目的に NA 開始 & 14 \\
& 経過観察 & 79 \\
\hline HCV 抗体陽性 & 肝細胞癌 & & 3 (他院加療中 1 例) \\
& 肝硬変 & DAA 開始 & 4 \\
& 慢性肝炎 & 肝庇護療法 & 2 \\
& & DAA 開始 & 28 \\
& & 他院 DAA 治療中 & 1 \\
& 経過観察 & 16 \\
& & 13 \\
& SVR 後 & & 154 \\
\hline
\end{tabular}

$\mathrm{NA}$; 核酸アナログ製剤, SC ; セロコンバージョン, DAA；直接作用型抗ウイルス薬, SVR：ウイルス学的持続陰性化 


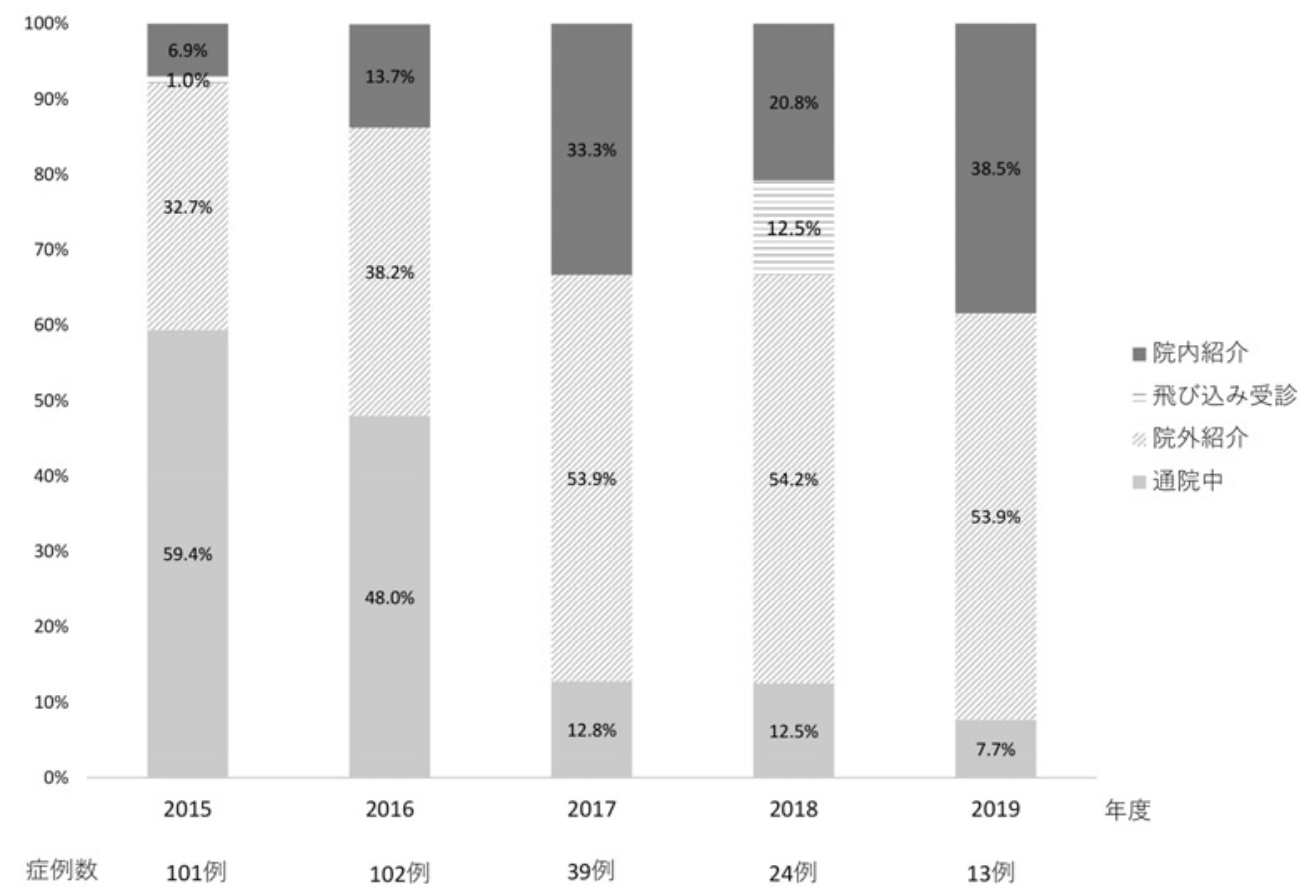

図 5 当科における DAA 治療症例の受診契機

2015 年 4 月から 2019 年 12 月に当院で DAA 治療を受けた患者の受診契機を通院中, 院外紹介, 飛び 込み受診 (紹介状なく外来受診), 院内紹介の 4 群に分類.

あり, 十分とは言えず, さらなる対策が必要と考えた. そこで, 電子カルテアラートシステムとは独立した受 診勧奨の取り組みとして多職種連携による新たなシス テムを構築することとした．臨床検査技師は日常業務 において，血液検查を測定し，最初に結果判定を確認 する職種である。臨床検査技師を含む多職種連携を構 築し，臨床検査技師に 1 週間毎の肝炎ウイルス陽性者 の把握を依頼，臨床検查技師より報告を受けた看護師 および肝臓専門医が主治医に個別忤奨を実施した結果, $92.0 \%$ と高い対応率が得られた.この結果から多職種連 携による個別受診钓奨は，これまでの電子カルテ自動 アラートシステムや診療科毎の勉強会と比べて非常に 高い効果があることを示しており，電子カルテアラー 卜に相乗的効果があると考えられた。また，受診勧奨 を担当する肝臟専門医の連絡先を揭示板に記載するこ とで，主治医より個別の相談を受けることができ，院 内紹介への理解にもつながり, 検討期間以降も $85 \%$ 以 上の高い対応率を維持している.

一方で，当院は県の肝疾患診療連携拠点病院である とともに, 高度救急医療機関でもある。短期入院も多
く, 1 週間毎の対応では不十分であることも懸念された が，個別勧奨を開始した 2019 年 7 月から 12 月におけ る未対応患者は 9 例のみで，そのうち 2 例は救急外来 受診後死亡例, 2 例は末期癌患者であり, 肝炎ウイルス に対する精查加療が必要と判断されるほとんどの症例 に対応が行えていた．しかし，他の未対応症例は，1 日のみ外来受診された症例が 2 例，短期入院症例が 2 例，長期的に通院中にもかかわらず未対応が 1 例であ り，やはり非専門医への啓発の継続も必要である。

今回当院で実施した多職種連携による個別勧奨では, 一週間毎の肝炎ウイルス検查陽性者は週 5 名程度であ り, 担当する臨床検査技師や看護師の業務の負担は少 ないことが判明し, 継続可能な取り組みであるととも に他の医療機関でも実施可能な取り組みであると推測 する．現在，全国で肝炎医療コーディネーターの養成 が進んでおり, 山口県でも「山口県肝疾患コーディネー ター」の名称にて 2012 年より肝炎医療コーディネーター の養成を開始し, 500 名以上のコーディネーターが養成 されており，職種としては看護師が最も多いが，臨床 検查技師もコーディネーター取得者が多い職種である ${ }^{11}$. 
院内受診勧奨の取り組みは肝炎医療コーディネーター としての臨床検查技師の重要な役割であると考える. 今回実施した多職種連携による受診钊奨の取り組みは, 電子カルテ自動アラートと異なり，特殊なシステムを 必要とせず, 広く普及可能な取り組みであり, 現在県 内の肝疾患専門医療機関を中心に市中病院でも実施が 広がっている．今後多施設での有用性を検証していき たい.

今回の検証の結果, 院内受診から肝臟内科紹介となっ た症例において, B 型慢性肝炎・肝硬変症に対する核酸 アナログ製剂投与が開始となった症例や C 型慢性肝炎・ 肝硬変で DAA 治療が開始となった症例を多く経験した. さらに, 本来であれば HBV 再活性化予防対策が必要で るにもかかわらず未対応である症例も, 受診勧奨アラー 卜後の院内紹介で掘り起こされた.

また, 当院におけるDAA 治療症例における受診契機 は変化しており, 新規症例数は減少傾向にあるなかで, 院内受診勧奨の割合は増加している．院内受診勧奨の 取り組みは, 残されたウイルス性肝炎患者への適切な 治療介入につながる重要な取り組みであると認識した。

\section{結 語}

非専門診療科に個別に勉強会を実施することは，電 子カルテ自動アラートシステムによる肝炎ウイルス陽 性者に対する院内受診勧奨の有効活用につながる。ま た，多職種連携による個別勧奨は院内受診钓奨の取り 組みとして非常に有用である.

倫理：本検討は山口大学医学部附属病院臨床研究センター の倫理審查承認（H2020-146）を得て実施した。

\section{文献}

1) Tanaka J, Akita T, Ko K, et al. Countermeasures against viral hepatitis B and C in Japan: An epidemiological point of view. Hepatol Res 2019; 49: 9901002

2) Tateishi R, Uchino K, Fujiwara N, et al. A nationwide survey on non-B, non-C hepatocellular carcinoma in Japan: 2011-2015 update. J Gastroenterol 2019; 54: 367-376

3) Liaw YF, Sung JJY, Chow WC, et al. Lamivudine for patients with chronic hepatitis B and advanced liver disease. N Engl J Med 2004; 351: 1521—1531

4) Hosaka T, Suzuki F, Kobayashi M, et al. Long-term entecavir treatment reduces hepatocellular carcinoma incidence in patients with hepatitis B virus infection. Hepatology 2013; 58: 98-107

5) Waziry R, Hajarizadeh B, Grebely J, et al. Hepatocellular carcinoma risk following direct-acting antiviral HCV therapy: A systematic review, metaanalyses, and meta-regression. J Hepatol 2017; 67: 1204-1212

6) Oza N, Isoda H, Ono T, et al. Current activities and future directions of comprehensive hepatitis control measures in Japan: The supportive role of the Hepatitis Information Center in building a solid foundation. Hepatol Res 2017; 47: 487-496

7) 打田 (小林) 佐和子, 榎本 大, 藤井英樹, 他. 当 院における肝炎ウイルス検査の実施状況と陽性者に 対する受診勧奨システム構築による院内連携の変化 について. 肝蔵 2016; $57: 7-16$

8) Fujii H, Yamaguchi S, Kurai O, et al. Putting "sticky notes" on the electronic medical record to promote intra-hospital referral of hepatitis B and hepatitis $\mathrm{C}$ virus-positive patients to hepatology specialists: an expoloratory study. BMC Infect Dis 2016; 16: 410

9) Hidaka I, Enomoto M, Sato S, et al. Establishing Efficient Systems through Electronic Medical Records to Promote Intra-hospital Referrals of Hepatitis Virus Carriers to Hepatology Specialists: A Multicenter Questionnaire-based Survey of 1,281 Healthcare Professionals. Intern Med 2021; 60: $337-343$

10）下村康之, 藤井洋輔, 池田房雄, 他. 肝炎ウイルス 検査陽性者に対する検査報告システムの効果的な運 用方法一肝臓専門医受診率向上のさらなる工夫一. 肝臓 $2017 ; 58$ : 427-434

11）日高 勲, 坂井田功. 山口県における肝炎対策の現 状. 肝臓クリニカルアップデート $2020 ； 6: 277$ 280

本論文内容に関連する著者の利益相反 :

講演料：日高勲；アッヴィ合同会社, ギリアド・サイ エンシズ, 坂井田功; ギリアド・サイエンシズ, 奨学 寄付など：日高 勲；アッヴィ合同会社, 坂井田功；アッ ヴィ合同会社 


\title{
Promotion of intrahospital referral of hepatitis virus-positive patients to hepatology specialists through interprofessional collaboration, including clinical laboratory technicians
}

\author{
Isao Hidaka ${ }^{12) *}$, Takashi Oono ${ }^{1)}$, Aki Fujinaga ${ }^{3)}$, Miyuki Masui ${ }^{4)}$, Takuro Hisanaga ${ }^{2)}$, \\ Issei Saeki ${ }^{22}$, Toshihiko Matsumoto ${ }^{2)}$, Yoshio Marumoto ${ }^{2)}$, Tsuyoshi Ishikawa ${ }^{2}$, \\ Taro Takami ${ }^{2}$, Reo Kawano ${ }^{5}$, Takahiro Yamasaki ${ }^{33}$, Isao Sakaida ${ }^{122}$
}

Hepatitis virus tests are commonly performed, particularly for preoperative assessment. Although with a limited effect, alert systems in electronic medical records are a measure to promote the referral of hepatitis virus carriers to hepatology specialists. Additionally, our hospital has been conducting study sessions for nonspecialized clinical departments and individual recommendations through interprofessional collaboration, including clinical laboratory technicians. The response rate to patients positive for hepatitis virus in each nonspecialized clinical department increased after the study sessions. Furthermore, it increased dramatically to $92.1 \%$ after individual recommendations through interprofessional collaboration. Of all patients with internal referrals to hepatologists through recommending consultation, 20 patients with hepatitis B started nucleotide analogs, and 32 patients with hepatitis $\mathrm{C}$ started direct-acting antiviral (DAA) therapy. Moreover, the rate of internal referrals increased as a consultation opportunity for cases treated with DAAs. Study sessions in each clinical department and individual recommendations through interprofessional collaboration are useful for recommending intrahospital consultations.

Key words: hepatitis virus recommending consultation interprofessional collaboration hepatitis medical coordinator clinical laboratory technician

Kanzo 2021; 62: 448-455

1) Center for Liver Disease, Yamaguchi University Hospital

2) Department of Gastroenterology \& Hepatology, Yamaguchi University Graduate School of Medicine

3) Division of Laboratory, Yamaguchi University Hospital

4) Division of Nursing, Yamaguchi University Hospital

5) Clinical Research Center in Hiroshima, Hiroshima University Hospital

*Corresponding author: isao-h@yamaguchi-u.ac.jp

C 2021 The Japan Society of Hepatology 